\section{Professional Languages Alone Do Not Suffice for Successful and Socially Responsible Internal Communication between Different Cultures}

\section{Darja Kukovec}

PhD student at the University of Maribor, Faculty of Economics and Business, Slovenia

darja.kukovec@student.um.si

\section{Matjaž Mulej}

University of Maribor, Faculty of Economics and Business, Slovenia matjaz.mulej@um.si

\section{Simona Šarotar Žižek}

University of Maribor, Faculty of Economics and Business, Slovenia simona.sarotar-zizek@um.si

\begin{abstract}
Successful internal communication in an intercultural environment depends on the organizational culture, business environment, social responsibility, and leaders' skills. Thus, internal communication and employee adaptation to changing business environments ask what a successful socially responsible internal communication requires. This contribution discusses theoretical foundations of qualitative research, how the organizational culture can define which direction the organization should chose to attain social responsibility, and how internal communication can improve understanding of professional language and be decisive in a working environment. The generated model offers insights into understanding social responsibility and organizational culture to improve internal communication.
\end{abstract}

Keywords: organizational culture, social responsibility, communication, internal communication, business languages.

\section{Introduction}

Leading a successful organization is difficult. Employees are their organization's living workforce; their adaptation to new business environments crucially has an impact on business success. This proposes the question of whether knowledge of professional languages is enough for successful internal communication of different cultures, along with other questions, such as how much the knowledge of organizational culture matters in an organization for internal communication. One must understand how organizational communication matches social responsibility, too.
ORIGINAL SCIENTIFIC PAPER

RECEIVED: APRIL 2018

REVISED: JUNE 2018

ACCEPTED: AUGUST 2018

DOI: 10.2478/ngoe-2018-0017

UDK: 005.73:005.35:81'24

JEL: M14

Citation: Kukovec, D., Mulej, M., \& Šarotar Žižek, S. (2018). Professional Languages Alone Do Not Suffice for Successful and Socially Responsible Internal Communication between Different Cultures. Naše gospodarstvo/ Our Economy, 64(3), 47-55.

DOI: 10.2478/ngoe-2018-0017

\section{NG OE}

NAŠE GOSPODARSTVO OUR ECONOMY

Vol. 64 No. $3 \longdiv { 2 0 1 8 }$

pp. $47-55$ 
In order to address the challenge of successful and socially responsible internal communication in different business environments, the authors structured this article into several chapters. The methodology of the research is presented in Chapters 2, 3, 4, and 5, in which the authors examine the theoretical foundations of organizational social responsibilities, organizational culture, and internal communication. The authors further search for interaction between theoretical foundations to better understand successful internal communication and indicate that simply understanding that knowledge of professional languages for successful internal communication may not be enough. The authors of this article ask two main questions: 1) Do business environment, social responsibility, and organizational culture affect successful internal communication? 2) Is business language enough for successful internal communication? Hence, the authors present two important hypotheses:

H1: Business environment, social responsibility, and organizational culture affect the success of internal communication.

H2: Business languages only partially suffice for success of internal communication.

For their theoretical research, the authors used scientific description, which helped them to define theoretical starting points on organizational culture, internal communication, social responsibility, and professional languages. The authors also used the comparison method. Thus, the authors explored and compared different theoretical starting points and facts. The methods of deduction and induction have a significant influence on the research, which helped the authors reach important conclusions. At the end of this paper, the authors define the practical purpose of their research.

\section{Methodology}

The authors begin with a literature review on the findings of Slovene and global foreign authors on the organizational culture, internal communication, social responsibility regarding the leadership skills, and role of business languages.

Researchers' "biases" also belong to the majority limitations of this article, including the authors' relationship to the problem under research. The authors explain their reasons for researching it, i.e., to increase their credibility. It is important to select a dialectical system of perspectives on the same topic (Mulej, 1979).

To match the selected limits, the authors used the following keywords: social responsibility, organizational culture, organizational culture analysis, internal communication, and business languages for the databases Google Scholar,
Cobbis.si, and Scopus. The authors found in Google Scholar 31 sources linking corporate social responsibilities and organizational culture; in Cobbis.si, 22 sources; in Scopus, nine source. Links between corporate social responsibilities and internal communication were found in Google Scholar in over 200 sources; in Cobbis.si, 12 sources; in Scopus, one source, only two works on the authors' topic were found similar, which proved beneficial for this work. The first used article researched coherence between organizational culture and changes in corporate social responsibility in an economic downturn (Jaakson et al., 2012); the second described a variety of perspectives on corporate social responsibility (McWilliams et al., 2006). Jaakson et al. (2012) explored manifesting of different types of organizational culture in certain corporate social responsibility activities to uncover how the presence of certain types induces changes in social responsibility caused by drastic shifts in the economic environment. McWilliams et al. (2006) offer a good indicator of a variety of perspectives on corporate social responsibility, which were used to develop a framework for consideration of the strategic implications of corporate social responsibility.

The method used, i.e., single case study, serves as an exploratory study.

\section{Corporate Social Responsibility}

In its globally official (and sense-making) definition (in ISO 26000), the social responsibility means one's responsibility for one's influences over society, i.e., humans and nature, reaching beyond and including legal obligations (ISO, 2010). Social responsibility belongs to human attributes expressed with seven principles in ISO 26000, i.e., accountability; transparency; ethical behavior; respect for stakeholders; respect for rule of law; respect for international norms; respect for human rights; crucial are two concepts from systems theory: interdependence and holistic approach (ISO, 2010). Thus, social responsibility should replace, in a nontechnological innovation process, the current abuse of the government and market by the most influential persons via neoliberalism. This will require innovation of values, culture, ethics, and norms and can hardly result from activities of humans with no (positive) mental toughness (e.g., Potočnik, 2016; Zupančič, 2016; Cunk, 2016; Felber, 2012; Štrukelj, Boršič, 2014; Štrukelj, 2015; Rašič, 2015; Schwab, 2016; Gostiša, 2017).

Originally, one saw in social responsibility a human attribute; later one started discussing corporate social responsibility (Zore, 2016). However, organizations make no decisions and undertake no actions; they are tools of decisive persons. Companies are called "legal entities" to diminish the humans' individual responsibility and to divide it from decisive humans’ 
rights. (See contributions in Hrast eds., 2016-2017; Mulej \& Dyck, ed., 2014 \& 2015 [four books]; Mulej et al., ed., 2013, 2014, 2015 [three guest-edited journal issues]; Mulej et al., ed., 2016 [three books]; Gostiša, 2014 \& 2017; etc.)

Wartick and Cochran's (1985) model for corporate social responsibility redefined Carroll's (1979) four dimensions of corporate social responsibilities as the "principles of corporate social responsibility.” Hence, an organization's culture would form the basis to formulate and manage its social responsibilities. The corporate social responsibility dimensions and activities that are most relevant to the business environment in developing countries relate to workplace, society, and environment (Visser, 2005).

Social responsibility constitutes a strong commitment to social obligations via the organizational culture emphasizing the execution of organization's obligations toward its employees and other stakeholders (Sharma et al., 2009, p. 207 in Milfelner et al., 2015, p. 222). A good definition of corporate social responsibility, with a common terminology, as in ISO 26000 (ISO, 2010), aids humans in modeling the role of organizational culture and leadership in determining the importance of their corporate social responsibility. Researchers now can analyze how changes in corporate control, particularly through mergers or acquisitions, affect the type and level of corporate social responsibility activity in organizations (McWilliams et al., 2006).

Analysis of the strategic implications of corporate social responsibility is hampered by cross-country/cultural differences in the institutions that regulate market activity, including businesses, labor, and social agencies. Environmental differences lead to different expectations and returns to activity. For companies operating in multiple countries/cultures, this complicates the decisions on which activities to engage in and how much to invest. As the knowledge base on corporate social responsibility develops worldwide, one will be better able to analyze and advise on corporate social responsibility regarding an organizational culture (McWilliams et al., 2006).

\section{Organizational Culture}

The literature in the 1980s (Peters \& Waterman 1982) discussed organizational culture and explored the success of Japanese companies (Ouchi, 1981; after Alvesson, 2002). In early 2000, authors started to define organizational culture as a comprehensive system of norms, values, notions, beliefs, and symbols (Rozman 2007, 2008, \& 2010; Schein, 1990; Denison et al., 2012; Fullan, 2014, pp. 5-6; Verčič, Verčič \& Sriramesh, 2012; Schein 2010). Sweeney and McFarlin (2002, p. 336) define organizational culture as beliefs, values, and behavior, which are visible internally and externally. "How we do things around here” reads their understanding of it.

Many authors on organizational changes involve organizational culture in one sense or another (Alvesson \& Sveningsson, 2008, p. 15). Their common denominator may be social responsibility, exposing responsibility, interdependence, and holism (ISO, 2010; EU, 2011) and principles and measures of business innovation as integral parts of the values, organizational culture, ethics and norms of behavior. Their implementation should make employees, for normal egoistic reasons, be less selfish (short-term and narrow-minded) than in the previously dominant practice. Therefore, the solution to the problem can be found in the new synergy of knowledge of the growing dominance of the creative class, requisite holism, and social responsibility, thus replacing affluence as a dead-end; the new motivation lies in proper organizational culture, which would lead also to employees' creativity-based well-being (Žižek et al., 2009a, p. 9). Culture is often either the key issue to be changed or something that one must take seriously to enable change (Dauber et al., 2012).

\section{Modifying the Organizational Culture}

One must define the norms and values of organizational members who interact with organizational internal communication to understand an organizational culture better (Treven, 2001, p. 45).

When companies are expanding into other countries, leadership must become much more sophisticated, and the companies must prepare their employees to adapt to the new culture and communication, putting the new organizational culture in the framework of social responsibility (Fullan, 2014, pp. 5-6). Some authors (Alvesson \& Sveningsson, 2008) suggest that the frequent neglect of the aspect of organizational culture is a major reason why organizational change efforts often fail to match the plan. Few if any organizational changes navigate around culture rather than tackle cultural changes. The organizational change involves confronting the persistent pattern of behavior that is blocking an organization's higher performance, diagnosing its consequences, and identifying the underlying assumptions and values that have created it. At a minimum, culture may create problems and deserves consideration. This demands a look beyond surface and at the meaning, definitions, and identities of the people involved (Alvesson \& Svenigsson, 2014).

Many researches confirmed the effect of organizational culture and knowledge on sharing behaviors, especially those that matters for social responsibilities (Bhatt, 2001; Koskinen eds., 2003; Arenius eds., 2003). 
Organizational configuration is any multidimensional constellation of conceptually distinct characteristics that commonly occur together (Meyer \& Hathaway, 1993). With this kind of analysis and the possibility of subsequent business environment changes, management can carry out such an analysis successfully with the help of internal communication (Meyer \& Hathaway, 1993). Analyzing and changing internal communication regarding the business environment and social responsibilities is important and complex. Thus, global organizations must support organizational values such as openness to change and learning, including adoption of values of social responsibility, ethical behavior (Keyton et al., 2012, pp. 13-15).

\section{Internal Communication}

Every employee has information that is necessary for the entire staff and critical for the successful internal communication and, consequently, the social responsibilities (Thill \& Bove, 2002). If one poorly understands the organizational culture, one's expert knowledge of languages will not enable successful communication; it might cause the failure of it, which in turn will lead to organizational and individual stress. Then, one will realize that a successful internal communication (Možina et al., 2004) demands several interaction skills for successful leadership. They include the employees' socialization, identification with their organization, training, information, animation, motivation and loyalty, knowledge of the organizational culture, social responsibility, etc. Then, the professional languages will matter more because the goals will be clear.

Poor internal communication indirectly causes poor organizational performance: employees lose confidence in their leaders (Bitenc, 2006), especially if they detect that the organizational culture is neither matching social responsibility nor their own values regarding the organizational culture. Employee satisfaction drops, and (good?) organizational results can no longer make them loyal to an organization. Employee dissatisfaction causes poor work performance, more absence, grouping, poor work quality, and a lack of interest in creating progress - all of which causes long-term problems in the organization's operations.

\section{Model of Successful and Socially Responsible Internal Communication}

The resulting new management model of successful and socially responsible internal communication matters (Figure 1). It can help one understand the preconditions for succesful social responsible internal communication when an organization is in a new business environment and is confronting different business cultures.

Successful and socially responsible internal communication in multinational organizations demands perception of the national (and regional) culture and its role in internal communication in a multicultural business environment. To understand this connection, first, one must determine the culture's influence on employees' behavior, which consequently affects the values and norms of organizational culture or can even break social responsibility. The interaction between national culture in a new business environment and expanded organization is shown in the authors' model of successful and socially responsible internal communication (see Figure 1).

Why is understanding of internal communication important and why is such a model necessary? There are many reasons, including the succesful organization's performance based on realizing its social responsibility, which the authors included (Figure 1). Waldman et al. (2004) apply strategic leadership theory to corporate social responsibility because certain aspects of transformational leadership are positively correlated with the propensity of organizations to engage in corporate social responsibility. These leaders employ corporate social responsibility activities strategically (McWilliams et al., 2006). This means that corporate social responsibility is also visible in employees' health, administrative innovation, business learning, life-long learning, and environmental questions, which directly reflect in an organization's leadership and organizational culture (Terpstra \& Sarathy, 2000, p. 91). One proves many links of corporate social responsibility to the organizational strategy (Waldman et al., 2006; McWilliams et al., 2006; McWilliams \& Siegel, 2001; Baron, 2001; etc.), but links to the internal communication are still poorly researched.

For successful and socially responsible internal communication, one must know the differences of organizational cultures between various business environments and their characteristics (see Figure 1). Differences between cultures cause invisible barriers, which one can be overcome with knowledge and willingness to change the latter for a successful operation within the organization. If knowing and understanding the cultural differences of a business environment within social responsibility, managers can direct their employees in the right direction with succesful internal communication. Taking into account cultural characteristics and business practices of other countries matters for successful business and competitiveness (Brenčič \& Hrastelj, 2003, p. 261).

Diversity of languages is a major difference in cultures (Terpstra \& Sarathy, 2000, p. 94), i.e., language expresses 
character and values of a culture but not an organizational culture itself, which depends on other norms, beliefs, etc. Based on that, the authors can claim that knowing and speaking another language is a first step toward knowledge of foreign country's culture, but neither toward knowledge of values of the organizational culture and corporate social responsiblities nor toward successful and socially responsible internal communication (Cateora \& Graham 2002, p. 106).

\section{Discussion and Implications}

This article can help humans to realize that knowledge of professional foreign languages alone is not enough for successful and socially responsible internal communication between different cultures. Organizational culture differs from organization to organization and requires analysis for people to understand by which principles employees work and what are the goals of successful internal communication within social responsibilities as tools of the whole organization regarding their new business environment.
In regard to the first question of this article, if the business environment, social responsibility, and organizational culture affect succesful internal communication, the authors can respond positively. The authors can add that one's knowledge of language barriers and understanding of intercultural organizational differences within the organization in other business environments can enable a successful organizational operation. Knowledge of a professional language is an important skill for highly qualified personnel, but understanding an organizational culture matters even more in successful internal communication, i.e., it shows the values and norms that are necessary for the successful operation of an organization, considering organizational cultures within social responsibilities.

The second question of this article asks if business languages alone suffice for successful internal communication. Thus far, the authors claimed that the importance of knowledge of foreign languages grows only when organizations are aware of their organizational culture and corporate social responsibilities regarding their business environment. Knowledge of foreign languages is an employees' indispensable competence; it belongs in an organization's objectives and vision.

Figure 1. Integrated Model of Successful and Socially Responsible Internal Communication

\section{ORGANIZATION}

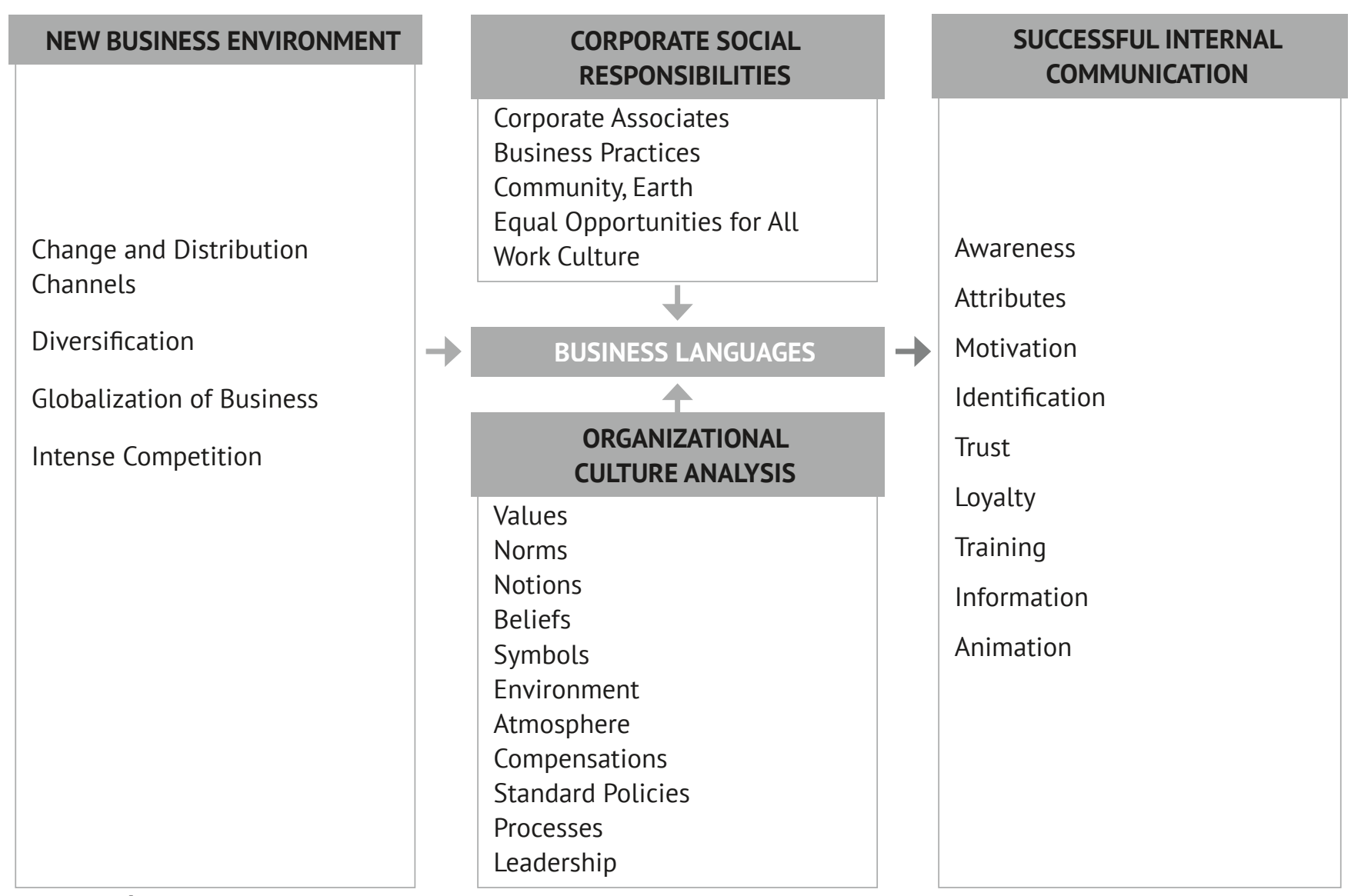


But which foreign specialized language is the "essential" one for a successful business? From the literature (Wright 1999, p. 199), one can see that English is the official global working language in politics, economy, defence, judiciary, and culture. Language can achieve a global status in society only if it is globally recognized and widespread at ethnically heterogeneous political, economic, and other organizations (Crystal, 1997; Muha, 2003).

Relationships among a business environment, social responsibility, organizational culture, and internal communication are shown via comparison method in the first five chapters of this study, where the authors first used methods of scientific description and defined theoretical starting points. Chapter 6 discusses the followed methods of deduction and induction, where the authors make important conclusions from their theoretical research. With the help of the induction method, the authors created their hypotheses. The authors (Crystal, 1997; Muha, 2003; Wright, 1999, p. 199; Thill \& Bovee, 2002, p. 165; Cateora \& Graham, 2002, p. 106, et al.) claim that successful internal communication depends on many different factors such as understanding of organizational culture, organization strategy, intercultural competence, organizational enviroment, etc. Hence, the authors of this article support Hypothesis 1 and claim that business environment, social responsibilities, and organizational culture affect the success of internal communication. The second essential question asks if the knowledge of professional languages alone suffices for the successful internal communication. Several authors (Crystal, 1997; Muha, 2003; Wright, 1999, p. 199; Thill \& Bovee, 2002, p. 165; Cateora \& Graham, 2002, p. 106, et al.) claim that knowledge of business language is important, but it is not the only factor that matters for successful internal communication. Thus, the authors of this article support and accept Hypothesis 2, which states that business languages only partially suffice for successful internal communication.

The authors (Terpstra \& Sarathy, 2000, p. 91; Mumel, 2008, pp. 187-188; Golobič, 2010, Lipičnik, 2005, et al.) claim that successful implementation of socially responsible internal communication requires control over its most common obstacles. Thus, the authors include the consequences of (1) the different meaning of information for individuals, (2) the false belief, (3) the mentality, the relationship between superiors and employees, (4) the characteristics of vertical and horizontal communication in the organization, (5) mutual distrust, (6) the transfer of only positive information in order to glorify oneself, (7) competitiveness, (8) too quick conclusions and other factors.

Further research should be based on the development of the questionnaire (measurement instrument) aimed to measure types of organizational culture and social responsibility regarding new business environments and business languages, which should be utilized in daily business. Measurements should support socially responsible internal communication in multinational organizations, which are often in different business environments.

\section{References}

Alvesson, M. \& Sveningsson, S. (2008). Changing organizational culture (pp. 4-18). New York: Routledge, Taylor \& Francis Group.

Alvesson, M. \& Sveningsson, S. (2014). Changing organizational culture. Second edition. London: Sage Page.

Alvesson, M. (2002). Understanding organizational culture. London: Sage Publication. https://doi.org/10.4135/9781446280072

Arenius, P., \& Minniti, M. (2003). Women in entrepreneurship. The entrepreneurial advantage of nations. First Annual Global Entrepreneurship Symposium, 29(1), 4-8.

Baron, D. P. (2001). Private politics, corporate social responsibility, and integrated strategy. Journal of Economics \& Management Strategy, 10(1), 7-45. https://doi.org/10.1111/j.1430-9134.2001.00007.x

Bhatt, R. M. (2001). World Englishes. Annual Review of Anthropology, 30(1), 527-550. https://doi.org/10.1146/annurev.anthro.30.1.527

Bitenc, P. (2006). Interno komuniciranje v podjetju Cordia [Internal communication in Cordia organization]. Ljubljana: Univerza v Ljubljani, Ekonomska fakulteta.

Carroll, A. B. (1979). A three-dimensional conceptual model of corporate performance. Academy of Management Review 4(4), $497-505$. https://doi.org/10.5465/amr.1979.4498296

Cateora, P. R., \& Graham, J. L. (2002). International Marketing, 11th edition. New York: McGraw-Hill Publishing.

Crystal, D. (1997). The language that took over the world. The Guardian, 22(21).

Cunk, Z. (2016). Presoja inovativnosti menedžerjev s kazenskopravnega vidika kot bistvenega kriterija družbene odgovornosti, doktorska disertacija [Assessment of Innovation Managers with criminal Law aspects as the crucial Criterium of Social responsibility, Doctoral Dissertations]. Maribor: Univerza v Mariboru, Ekonomsko poslovna fakulteta.

Dauber, D., Gerhard, F., \& Yolles, M. (2012). A configuration model of organizational culture. Sage Open, 1(1), 1-16. https://doi. org/10.1177/2158244012441482

Denison, D. eds. (2012). Leading culture chnge in global organizations: Aligning culture and strategy. San Francisco: John Wiley \& Sons.

Felber, C. (2012). Die Gemeinwohl-Ökonomie. Eine demokratische Alternative wächst. Wien: Deuticke im Paul Zsolnay Verlag. 
Darja Kukovec, Matjaž Mulej, Simona Šarotar Žižek: Professional Languages Alone Do Not Suffice for Successful and Socially Responsible Internal Communication between Different Cultures

Fullan, M. (2014). Leading in a culture of change personal action guide and workbook. San Francisco: John Wiley \& Sons.

Golobič, M. (2010). Transformation processes of Alpine landscapes and policy responses: top-down and bottom-up views. Society and Natural Resources, 23(3), 269-280. https://doi.org/10.1080/08941920802029177

Gostiša, M. (2014). Ekonomska demokracija kot nova sistemska paradigma kapitalizma [Economic democracy as a new systemic paradigm of capitalism]. Kranj: ŠCID.

Gostiša, M. (2017). Ekonomska demokracija v 21. Stoletju [Economic democracy in the 21st century]. Kranj: ŠCID - Študijski center za industrijsko demokracijo.

Hrast, A., Lorbek, D., Mulej, M., eds. (2015). Proceedings of all Ten IRDO International Conferences: Social Responsibility and Current Challenges. Maribor: IRDO - Institute for Development of Social Responsibility.

Hrast, A., Slapnik, T. \& Mulej, M. (2017). Nacionalna strategija družbene odgovornosti v Sloveniji - idejni osnutek [National strategy of social responsibility in Slovenia - Conceptual draft]. In: Mulej, M., \& Bergant, Ž. (2017). Družbena odgovornost in izzivi časa 2017: Dodana vrednost kot poslovna informacija z vidika družbene odgovornosti in trajnostnega razvoja podjetij [Value added as business information from the view of social responsibility \& enterprise sustainability] (pp. 13-16). Retrieved from www.irdo.si.

Hrastelj, T., \& Makovec-Brenčič, M. (2003). Mednarodno trženje [International marketing]. Ljubljana: Založba GV.

ISO (2010): 26000. Retrieved from http://www.iso.org/iso/discovering_iso_26000.pdf.

Jaakson et al. (2012). Is there a coherence between organizational culture and changes in corporate social responsibility in an economic downturn? Baltic Journal of Management, 7(2), 202-216. https://doi.org/10.1108/17465261211219813

Keyton, J. D., Ford, J., \& Smith, F. L. (2012). Communication, collaboration and identification as facilitators and constraints of multiteams systems. Multiteam Systems: An Organization Form for Dynamic and Complex Environments, 21, 173-190.

Koskinen, Y., eds. (2013). Corporate social responsibility and organization risk. Theory and empirical evidence (pp. 1- 64). Retrieved from http://www.ecgi.global/sites/default/files/working_papers/documents/SSRN-id1977053.pdf.

Lipičnik, B. (2005). Reševanje konfliktov, ne nasprotij [Conflict resolution, and not the opposite]. Ljubljana:Univerza v Ljubljani, Ekonomsko poslovna fakulteta.

Martin, R. (2002). Strong ties, weak ties and islands: structural and cultural predictors of organizational innovation. Industrial and Corporate Change, 11(3), 427-449. https://doi.org/10.1093/icc/11.3.427

McWiliams, A., Siegel, D. S., \& Wright, P. M. (2006). Corporate social responsibility; strategic implications. Journal of Management Studies, 43(1), 1-18. https://doi.org/10.1111/j.1467-6486.2006.00580.x

McWilliams, A., Siegel, D. S., \& Wright, P. M. (2006). Corporate social responsibility: Strategic implications. Journal of Management Studies $43(1), 1-18$

Meyer, S. D., \& Hathaway, W. (1993). Competition and cooperation in social movement coalitions. Lobbying for peace in the 1980 s. Berkeley Journal of Sociology, 38, 157-183.

Mihalič, R. (2006). Management človeškega kapitala [Human capital management]. Škofja Loka: Mihalič in Partner d.n.o.

Milfelner, B., Potočnik, A., \& Šarotar Žižek, S. (2015). Social responsibility, human resource management and organizational performance. System Research and Behavior Science, 32(2), 221-229. https://doi.org/10.1002/sres.2263

Možina, S., Tavčar, M., Zupan, N. \& Kneževič, N. (2004). Poslovno komuniciranje [Business Communication]. Maribor: Obzorja, založništvo in izobraževanje.

Mulej, M. \& Hrast, A. (2016). Nehajte sovražiti svoje otroke in vnuke, 2. knjiga [Stop hating your children and grandchildren, 2nd Book]. Maribor: IRDO- Institute for development of social responsibility.

Mulej, M. (1979). Creative work and dialectical systems theory. Maribor: Mladinska knjiga.

Mulej, M., \& Dyck, R., eds. (2014, 2015). Social responsibility beyond neo-liberalism and charity; four books. Shirjah UAE Bentham Science: E-book, 33 chapters, 48 authors from 13 countries 1. SR - A Non-Technological Innovation Process; 2. SR - Range of Perspectives per Topic and Countries; 3. SR - Sustainability, Education and Management and 4. SR - Methods, Dilemmas and Hopes.

Mumel, D. (2008). Komuniciranje v poslovnem okolju [Communication in a business environment]. Maribor: De Vesta.

Peters, T., \& Waterman, R. (1982). In search of excellence. London: Harper and Row.

Potočnik, A. (2016). Viabilna regija - rezultat inoviranja z dialektično teorijo sistemov in kibernetiko poslovnih sistemov, doktorska disertacija [Viable region - result of innovation process applying the dialectical systems theory and cybernetics of business systems, Doctoral Dissertation]. Maribor: Univerza v Mariboru, Ekonomsko poslovna fakulteta.

Quible, Z. K. (1991). Writing competencies needed by business employers. Delta Pi Epsilon Journal, 33, 33-51.

Radej, B., Golobič, M., \& Istenič, M. Č. (2010). Beyond new public management doctrine in policy impact evaluation. Slovenian Evaluation Society, Retrieved from:https://www.dlib.si/stream/URN:NBN:SI:DOC-1YD7BDLY/c93535f3-0157-4807-adaf-43303efde43c/PDF.

Rašič, K. (2015). Sistem indikatorjev tehnično-tehnoloških raziskav, inovativnosti in znanja na primeru tranzicijskega gospodarstva, doktorska disertacija [The system of the technical-technology research, innovation and knowledge indicators in a transitional economy, Doctoral Dissertation]. Maribor: Univerza v Mariboru, Ekonomsko poslovna fakulteta.

Rozman, R. (2007). Pomeni in zahtevnost analiziranja za boljše odločanje [Meaning and complexity of analysis for better decision making]. Zbornik referatov 13. strokovnega posvetovanja o sodobnih vidikih analize poslovanja in organizacije [Collection of $13^{\text {th }}$ edition of professional papers on professional consultations on modern aspects of business analysis and organization] (pp. 9-23). Portorož: Zveza ekonomistov Slovenije.

Rozman, R. (2008). Spreminjanje kulture $v$ združbah [Changing culture in organizations]. 9. znanstveno posvetovanje o organizaciji [9th Scientific consultation on the organization] (pp. 57-59). Ljubljana: Fakulteta za organizacijske vede. 
Rozman, R. (2010). Razmerja med organizacijskimi procesi upravljanja in ravnateljevanja, koordinacije in odločanja [Relationships between organizational processes of management and governance, coordination and decision-making]. In: 11. znanstveno posvetovanje 0 organizaciji: Koordinacijski in komunikacijski vidiki organizacije združb [11th Scientific organizational consultation: Coordination and communication aspects of the organization entities] (pp. 15-21). Ljubljana: Fakulteta za organizacijske vede UM.

Šarotar-Žižek, S. \& Mulej, M. (2013). Social responsibility: A way of requisite holism of humans and their well-being. Kybernetes, 42(2), 318-335. https://doi.org/10.1108/03684921311310639

Šarotar-Žižek, S., Mulej, M., \& Treven, S. (2009). Dobro počutje/subjektivna blaginja sodelavcev kot bistveni dejavnik prehoda v inovativno družbo [Well-being / subjective well-being of employees as an essential factor in the transition to an innovative society]. Organizacija, 42(3), A122-A132.

Šarotar-Žižek, S., Treven, S., \& Mulej, M. (2013). Creativity-based well-being of employees as a basis of future economy and society. Emerald Insight, 43(2), 210-227.

Schein, E. H. (1990). Organizational culture. American psychologist. San Francisco: A Wiley Imprint.

Schein, E. H. (2010). Organizational culture and leadership. San Francisco: John Wiley \& Sons.

Schwab, K. (2016). Četrta industrijska revolucija [Fourth Industrial Revolution]. World Economic Forum, Ženeva. Retrieved from: http:// assets.cdnma.com/8475/assets/Cetrta-industrijska-revolucija.pdf.

Štrukelj, T., \& Boršič, D. (2014). Inoviranje posameznika, podjetij in družbe za družbeno odgovornost in dobro počutje [Innovating individuals, organizations and society for social responsibility and well-being]. Maribor: Univerza v Mariboru, Ekonomsko poslovna fakulteta, 1 optični disk (CD-ROM).

Štrukelj, T. (2015). Dialektični sistem vidikov za inoviranje upravljanja in vodenja tranzicijskega podjetja [Dialectical system of viewpoints for innovating of governance and management of a transitional enterprise]. Maribor: Univerza v Mariboru, Ekonomsko poslovna fakulteta.

Sweeney, P. D., \& McFarlin, D. B. (2002). Organizational behavior, solutions for management. Boston: McGraw-Hill.

Terpstra, V., \& Sarathy, R. (2000). International marketing. Fort Worth: Dryden Press.

Thill, J.V., \& Bovee, C.L. (2002). Essentials of business communication. Boston: South End Press.

Treven, S. (2001). Mednarodno organizacijsko vedenje [International Organizational Behavior]. Ljubljana: GV.

Verčič, A.T., Verčič, D., \& Sriramesh, K. (2012). Internal communication. Definition, parameters, and the future. Public Relations Review, 38(2), 223-230. https://doi.org/10.1016/j.pubrev.2011.12.019

Vidovič-Muha, A. (2003). Sodobni položaj nacionalnih jezikov v luči jezikovne politike [Modern position of national languages regarding to the language policy] (pp. 5-25). Ljubljana: Filozofska fakulteta,.

Visser, W. (2005). Corporate citizenship in South Africa: A review of progress since democracy. Journal of Corporate Citizenship, 18, 18-20. https://doi.org/10.9774/GLEAF.4700.2005.su.00004

Waldman, D. A., et al. (2006). Cultural and leadership predictors of corporate social responsibility values of top management: A GLOBE study of 15 countries. Journal of International Business Studies, 37(6), 823-837. https://doi.org/10.1057/palgrave.jibs.8400230

Waldman, D.A., Ramirez, G. G., House, R.J., \& Puranam, P. (2004). Does leadership matter? CEO leadership attributes and profitability under conditions of perceived enviromental uncertainity. Academy of management Journal, 44(1), 134-143. https://doi.org/10.5465/3069341

Wartick, S. L., \& Cochran, P. L. (1985). The evolution of the corporate social performance model. Academy of Management Review, 10(4), 758-769. https://doi.org/10.5465/amr.1985.4279099

Wright, M. (1999). Influences on learner attitudes towards foreign language and culture. Educational Research, 41(2), 197-208. https:// doi.org/10.1080/0013188990410207

Zore, M. (2016). Krepitev inovativnosti podjetij v Sloveniji z razvojem družbene odgovornosti, doktorska disertacija [Strengthening Slovene Enterprises' Innovativeness By Development Of CSR, Doctoral Dissertations]. Maribor: Univerza v Mariboru, Ekonomsko poslovna fakulteta.

Zupančič, M. (2016). Inovacija upravljanja starejših znanjskih sodelavcev kot dejavnik inovativnosti in konkurenčnosti trga dela kot podsistema gospodarstva $v$ Sloveniji [Innovation of management of older knowledge workers as a factor of innovativeness and competiveness of the labour market as a subsystems of economy in Slovenia]. Maribor: Univerza v Mariboru, Ekonomsko poslovna fakulteta. 


\section{Authors}

Darja Kukovec is a master of business economics in the field of management. She received a master's degree at the Faculty of Economics and Business in Maribor in 2010. After that, she started her business career abroad as a financial assistant to the CFO of institution for nuclear energy. After one year of work experience, she continued her business career as a specialist in telecomunications purchasing. After more than two years of work experience, she became employeed as a project purchaser for People Development Trainings.

Matjaž Mulej. Born in 1941, is a doctor of economy (in systems theory) and of (innovation) management. He is Professor Emeritus of systems and innovation theory at the Faculty of Economics and Business, University of Maribor. He developed the dialectical systems theory and innovative business theory (covering transitional conditions). He has published (with coauthors, mostly) more than 1,800 texts (including more than 70 books/proceedings and more than 60 articles in first-class journals) in almost 50 countries. He served as a visiting professor abroad for 15 terms, including at Cornell University in Ithaca, NY. He is a member of three international academies of sciences and arts.

PhD Simona Šarotar Žižek is Associate Professor at the University of Maribor's Faculty of Economic and business. She holds a $\mathrm{PhD}$ in Economic and Business Sciences. She has been permanently completed her theoretical knowledge by practical work and career development in the Slovenian company Mura d. d. She joined University of Maribor, Faculty of Economics and Business in 2007 as Assistant Professor in the field of Human Resource Management. She is author or co-author of articles in several international and Slovenian journals and scientific and expert conferences. She is also the main leader of many international projects.

\section{Poklicni jezik ne zadošča za uspešno in družbeno odgovorno interno komunikacijo med različnimi kulturami}

\section{Izvleček}

$\mathrm{Na}$ uspeh notranje komunikacije $v$ medkulturnem okolju pomembno vplivajo organizacijska kultura, poslovno okolje, družbena odgovornost in veščine vodij. Za uspeh le-te in adaptacije zaposlenih na spremembe okolja je ključno, kaj je potrebno zanj glede na družbeno odgovornost. Članek predstavlja teoretična izhodišča kvalitativne raziskave in prikaže, kako lahko pravilno definirana organizacijska kultura v delovnem okolju ob upoštevanju poslovnega okolja pomaga izboljšati interno komunikacijo; pri tem izpostavi znanje tujih jezikov. $\vee$ članku je tako oblikovan model redne pozornosti na razumevanje družbene odgovornosti in organizacijske kulture, kateri izboljšuje notranjo komunikacijo.

Ključne besede: organizacijska kultura, družbena odgovornost, komunikacija, notranja komunikacija, poslovni jeziki 